\title{
The Flawed Borders of the Middle East
}

\author{
Xunheng $\mathrm{Wu}$ \\ ${ }^{1}$ History \& Political Science high-school student, Veritas Academy Kunshan Campus, Shanghai, China \\ *Corresponding author. Email: henry0729@sina.cn
}

\begin{abstract}
In this paper, I will be seeking to introduce the history and the reasons of how and why the flawed border of the Middle East was created after World War I. After World War I, Britain and France as two major ally powers who had defeated Ottoman attempts to divide up the Ottoman post-war territories. As a result, this irrational border was a product of Britain and France tried to expand their influence in the Middle East, instead of the political desire of the local Arabs. To prove this conclusion, I analysed multiple historical primary sources, such the content of Sykes-Picot Agreement, McMahon Hussein Correspondence, U.S King Crane Commission, and Conference of San Remo, as supporting evidence. The McMahon Hussein Correspondence and the U.S. King Crane Commission embodied the Arab demand for an independent Arab state at the time. Conversely, Sykes-Picot Agreement and the Conference of San Remo embodied the interests of European powers.
\end{abstract}

Keywords: Conference of San Remo, Sykes-Picot Agreement, McMahon Hussein Correspondence, U.S King Crane Commission, mandate, Leagues of Nation

\section{INTRODUCTION}

The recent history of the Middle East can be summed up in one word: chaos. The Middle East has been embroiled in multiple military conflicts, still so even today. Many of these conflicts stem from the irrational borders issues that started after World War I. But why were these borders created in that way? In this paper, I will seek to answer this question by investigating all the political conferences that shaped most of the region's borders. My analysis will show that the arrangement of the border was a flaw because it did not take into account the political desires of the Arab population.

\section{HISTORICAL BACKGROUND}

During World War I, most of the Arab-speaking provinces in the Ottoman Empire were the major battlefield in the middle east. Once the war ended in 1918, the Ottoman Empire as the vanquished country faced the carve-up from the ally power. At this point, British and French had already occupied most of the territories with their troops. By 1920, as the result of international powers and peace agreements, the final arrangement of the Middle
East border was made at the Conference of San Remo, the effect of which still influenced the map of the Middle East today.

\subsection{Sykes-Picot Agreement}

However, to find out how the border was reorganized on the Conference of San Remo we need to look back to the Sykes-Picot Agreement of 1916. This is the secret agreement between Britian and France on the division of territories in the Middle East after the fall of the Ottoman Empire. [4] Although the Russians did not sign the treaty, they recognized and accepted the terms of the Sykes-Picot Treaty, named after the negotiators, Francois Georges Picot, the French diplomat in Beirut, and Sir Mark Sykes, a senior British diplomat. [4] Under the agreement, the post-war Ottoman territory will be shared among Britian, France, and Russia. [4] According to which Britian was assigned Mesopotamia, modern Jordan, modern Kuwait, the northern coast of modern Saudi Arabia and the surrounding areas with seaports. [4] France was entitled with present-day Syria, modern Lebanon, northern Iraq, Mosul, Armenia and parts of south-central Turkey. Russia owned Constantinople, the Bosphorus, and most of the other four provinces 
closest to Caucasian Russia. [4]

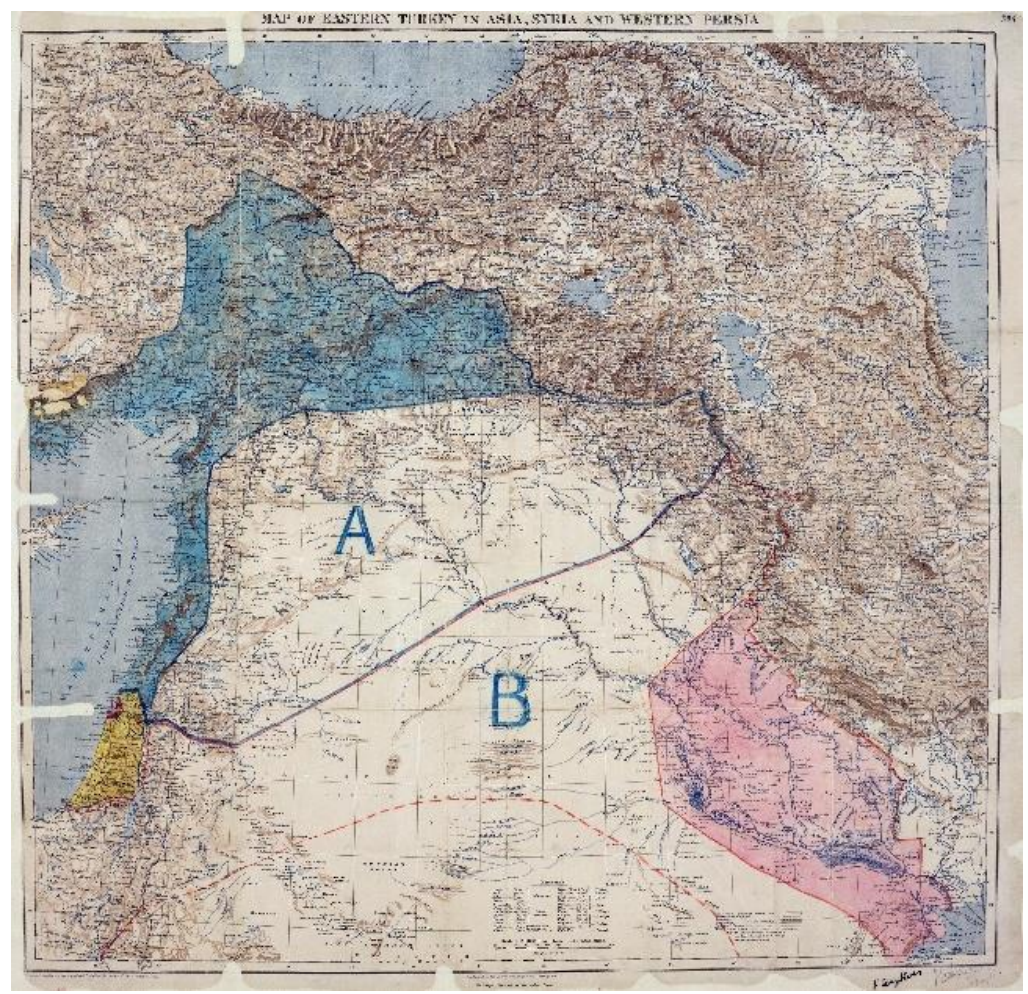

Figure 1 MPK1-426 Sykes Picot Agreement Map signed 8 May

\subsection{McMahon Hussein Correspondence}

However, the land arrangement in the Sykes-Picot Agreement is in contradict with the consensus made before it, the McMahon Hussein Correspondence. The McMahon Hussein Correspondence, an agreement made between Sir Henry McMahon on behalf of the British government and Hussein Bin Ali, a powerful religious leader in Mecca, guaranteed the local Arabs would establish their independent Arab Kingdom after the war. As Sir Henry McMahon wrote in the letter to Hussein Bin Ali,

"The two districts of Mersina and Alexandretta and protion of Syria lying to the west of the districts of Damascus, Homs,Hama, an Aleppo cannot be said to be purely Arab, and should be excluded from the limits demanded.

With the above modification, and without prejudice to our existing treaties with Arab chiefs, we accept those limits.

As for those regions lying within those frontiers wherein Great Britain is free to act without detriment to the interest of her ally, France, I am empowered in the name of the Government of Great Britain to give the following assurances and make the following reply to your letter:

1.Subjects to the above modification, Great
Britian is prepared to recognise and support the independence of the Arabs in all the regions within the limits demanded by the Sherif of Mecca.

2.Great Britian will guarantee the Holy Places against all external aggression and will recognise their inviolability." [8]

\subsection{Contradiction between two agreements}

These words promised exactly what the post-war independent Arab nation would be. However, after signing ceremony, Britain and France immediately negotiated the Sykes-Picot Agreement without informing the Arabs, amending direct jurisdictions and indirect administration areas under Britian and France. Those amendments were completely based on their economic and political interests, disregarding the local Arab population's will or the fair play clearly stated in the McMahon Hussein Correspondence. According to the Sykes- Picot Agreement:

"That in the blue area France, and in the red area Great Britain, shall be allowed to establish such direct or indirect administration or control as they desire and as they may think fit to arrange with the Arab state or confederation of Arab states." [10]

\subsection{Disclosure of the Sykes-Picot Agreement}

Moreover, every piece of information in the 
Sykes-Picot Agreement was kept as a secret, without informing Hussein Bin Ali, despite the fact that he and his people had been fighting along side with the British against the Ottomans since 1915. [11] It was not until November 24th, 1917, that the secrets of the Sykes-Picot Agreement were revealed by the Soviet government, by publioshing the copy of the agreement in Izvestia newspaper. [4] The disclosure of the secret is huge a political scandal, also became the turning point in the relations between the Arabs and the British and France, since the Britian violated its commitments under the McMahon Hussein Correspondence. [4] As time went by, tension between the different groups in the Middle East began to grow, the locals protest against the territorial planning and mandate system. But all this effort did not make any difference.

Eventually, in 1920, the final resolution was made during the Conference of San Remo based on the Sykes-Picot Agreement. [11] The decision was made that the Middle East will be divided into different sections of mandates by the League of Nations: Syria, Palestine, and Mesopotamia. The French received the mandate in Syria, and the British in Palestine and Mesopotamia. [11] However, the most special of these would be Palestine, because the British would include it as a direct jurisdiction for the settlement of Jewish immigrants in the Jewish State. [11]

\section{U.S KING CRANE COMMISSION}

Obviously, the result of Conference of San Remo was not what the local Arabs wanted to see. Thanks to the U.S King Crane Commission, it allows us to find out what the Arabs desired at that time. The U.S King Crane Commission is a report prepared by a commission led by two Americans, Henry Churchill King and Charles R. Crane, that was completed on 28 August 1919 and published in 1922. The Commission collected more than 1,800 petitions in the former Ottoman territories in 1919 to help guide American policy after the end of World War I. [3]

In the report, present-day Israel, Palestinian, Jordan, Lebanon and Syria were all considered to be part of the Greater Syria or Syria region at the time. [3] Page 15 and 16 from the original document released by the U.S. King Crane Commission contain detailed statistics from the 1,863 petitions in the Syria region.

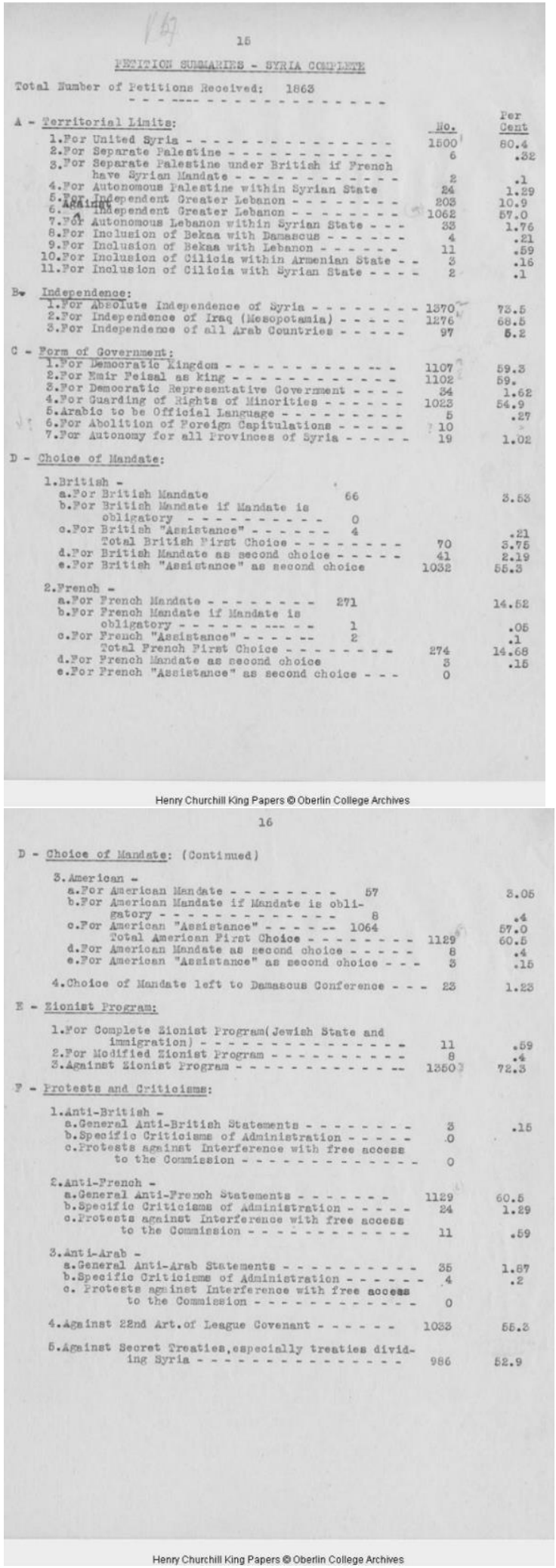

Figure 2 King-Crane Commission Report Pg 15-16

The report states that $80.4 \%$ of the 1863 petitions on the topic of "Territorial Limits" wanted a United Syria, at the time Syria was considered to include present-day Israel, Palestinian, Jordan, Lebanon and Syria. [6] Only $10.9 \%$ of the petitions wanted the independence of Greater Lebanon. [6] While 57\% of 
the petitions were against the independence of Greater Lebanon. [6]

Next, on the topic "independence", $73.5 \%$ of the 1863 petitions wanted an absolute independence of Syria, which was 1370 out of $1863.68 .5 \%$ of the petitions wanted an Independent Iraq, as known as Mesopotamia, and $5.2 \%$ of the petitions wanted independence of all Arab countries. [6]

Britian and France were considered as the class A mandate by the Leagues of Nation, as a result they became the mandatory power in the middle east. [6] However, according to the statistic collected by the commission, none of the foreign countries were actually welcomed in Syria as a mandate power, only earning around $5 \%$ in the total petitions. [6] What the Arabs were really looking for was the assistance provided by foreign countries, for example the United States was the first choice when $60.5 \%$ of the 1863 petitions wanted the U.S assistance. [7] Then the second choice was Britian, and the last was France.

The Commission also enquired local Arabs' opinions on the British Zionist Program. Only 11 petitions supported the Zionist Program. Unsurprisingly, $72.3 \%$ of the petitions were against the Jewish State and immigration. [7]

\section{REASONS}

There are three reasons why the Arabs could not fully establish their own independent state in the Middle East.

\subsection{European imperialism}

The first and most important reason was that the British and French simply didn't want the Arabs to gain independence, or in other words, Britian and France didn't want to see a self-governing Arab regime affect their interests and influence in the Middle East. The Sykes-Picot Agreement is a very good example of this. If Britain and France had not not acted soley in their own interests instead of carrying out responsibilities as great international powers, they would not have secretly planned their post-war territories behind the backs of their allies in the Middle East. Moreover, the mandate system finally decided in the Conference of San Remo is merely a cover of imperial colonization in the Middle East.

\subsection{Lack of Arab representaions}

Second, Leagues of nation and other conferences served only within the European countries. Most of the conferences that determine the future of the Middle East are organized by the Western powers themselves, when the native Arabs of the Middle East did not have much of a voice. [11] Take the Conference of San Remo as an example, the members of the conference who took part in this decision on the final resolution were the victors of the First World War. [11] None of the Arabs representatives or the Ottomans were invited to the meeting. [11] Therefore, it is obvious that the British and French would be able to carve up Arab territories with impunity, without having to face any opposing voices at the international occasions. [11]

\subsection{League of Nation}

Third, the oversight of the League of Nations is insufficient. [11] In theory, the National League should supervise how France and Britain enforce their duties as coercive states in the Middle East. The French and British must report their activities to the National League, and the National League could ask them for explainations on certain issues. [11] However, in fact the National League had little power. [11] Thus, the reality is that mandate system were little more than colonialization. This means that Britain and France are free to use their extensive powers to advance their own agendas and limit any moves toward political independence for Arabs in the region. [11]

\section{IMPACT OF THE BORDER}

The impact of this unreasonable border arrangement can be imagined. Political unrests and ethnic conflicts all stemmed from this political border arrangement demanding presence of the outsiders. In fact, a lot of national border lines in the Middle East that were still used today seriously violate the religious unity, national unity and linguistic consistency of a country. Take Syria as an example. First of all, the ethnic diversity of Syria is very diverse, including over 7 ethnics in the region. [1] Secondly, Sunni and Shia were both divided inside the border of Syria, and the languages of the different regions are different, so it is natural that such a very diverse region is both political and socially unstable. [1]

One of the great problems of the 20th century, which also originated in the border of Middle East, the Zionism that the British have been pushing so hard since World War I. British's ambition on establishing a Jewish homeland started from the Balfour Declaration in 1917. [5] Later, this protocol was enforced after British earned its mandate of Palestine. [5] This act was met with massive Arab protests from the outset. [2] But since World War II, Jews have immigrated in large numbers to the Palestine and eventually established Israel through a 
UN resolution. [2] Without considering whether Israel should have been created, but at least we see that the will of the Arabs has always been ignored by the British. Israeli-Palestinian conflict. This has led to the continuation of the Israeli-Palestinian conflict to this day, in which there have been many wars, such as the Middle East War.

\section{CONCLUSION}

The middle east peace have been exhausting to many generations since its effect and still many onwards. Had the super international powers acted altrusitcally and avoided doule-dealing at the moment, the chaos would have been much less frequent in the news. This should be lesson learned from unfair international treaties for us today: to leave no chaos for the future.

\section{REFERENCES}

[1](@TarekmOsman), Tarek Osman. “Why Border Lines Drawn with a Ruler in WW1 Still Rock the Middle East." $B B C$ News, BBC, 14 Dec. 2013 ,

www.bbc.com/news/world-middle-east-252995 53.

[2]Beauchamp, Zack. "What Are Israel and Palestine? Why Are They Fighting?” Vox, Vox, $20 \quad$ Nov. 2018, www.vox.com/2018/11/20/18080002/israel-pal estine-conflict-basics.

[3]ECF Database. King-Crane Commission Report (1919), ECF Database, ecf.org.il/issues/issue/1367.

[4]Jazeera, AL. "A Century on: Why Arabs Resent Sykes-Picot." Why Arabs Resent Sykes-Picot, interactive.aljazeera.com/aje/2016/sykes-picot100-years-middle-east-map/index.html.

[5]Khan Academy. "Sykes-Picot Agreement and the Balfour Declaration (Video)." Sykes-Picot Agreement and the Balfour Declaration, Khan Academy, www.khanacademy.org/humanities/world-histo ry/euro-hist/middle-east-20th-century/v/sykes-p icot-agreement-and-the-balfour-declaration.

[6]King, Henry Churchill, and Charles R. Crane. "King-Crane Commission Report, Submitted by Charles R. Crane and Henry Churchill King, 28 August 1919." King-Crane Commission Digital Collection, Oberlin College Archives, dcollections.oberlin.edu/digital/collection/kingc rane/id/598.
[7]King, Henry Churchill, and Charles R. Crane. "King-Crane Commission Report, Submitted by Charles R. Crane and Henry Churchill King, 28 August 1919." King-Crane Commission Digital Collection, Oberlin College Archives, dcollections.oberlin.edu/digital/collection/kingc rane/id/599.

[8]McMahon, Sir Henry. "The McMahon-Hussein Correspondence." Received by Sharif Hussein, The McMahon-Hussein Correspondence 14 July 1915 - 10 March 1916, Udel, 24 Oct. 1915, www1.udel.edu/History-old/figal/Hist104/asset s/pdf/readings/13mcmahonhussein.pdf.

[9]Royal Geographical Society. "MPK1-426 Sykes Picot Agreement Map Signed 8 May 1916." File:MPK1-426 Sykes Picot Agreement Map Signed 8 May 1916.Jpg, Wikimedia Commons, $7 \quad$ Oct. 2011, commons.wikimedia.org/wiki/File:MPK1-426_ Sykes_Picot_Agreement_Map_signed_8_May_ 1916.jpg.

[10]Sykes, Sir Mark, and Francois Georges Picot. The Avalon Project : The Sykes-Picot Agreement : 1916, Yale Law School, avalon.law.yale.edu/20th_century/sykes.asp.

[11]TheGreatWar. Spoils of War for Britain and France - Redrawing the Map of the Middle East I THE GREAT WAR 1920, TheGreatWar, 25 Apr. 2020, www.youtube.com/watch?v=qRsHqP-QHGQ 